\title{
Mathematical Ability of Elementary School Students Based on Cognitive Style and Gender
}

\author{
Ati Sukmawati, Delsika Pramata Sari, Mitra Pramita \\ Computer Science Education Department \\ Universitas Lambung Mangkurat \\ Banjarmasin, Indonesia \\ atiesukmawati@gmail.com
}

\begin{abstract}
The development of mathematical ability of elementary school students is very important. Education in elementary school is a foundation in mathematical ability at a higher level. In fact, many things can affect students' mathematical ability both physically and mentally of the students. The facts underlying this study were the mathematical ability of elementary school students based on cognitive style and gender. Therefore, the purpose of this study was to examine the cognitive style and gender of the elementary school students' mathematical ability. The employed method was survey method. The subjects of this study consisted of 141 elementary school students on the fourth grade. These elementary school students were scattered in five districts in Banjarmasin. The instruments used were mathematical ability items and Group Embedded Figure Test (GEFT) to determine the cognitive style. Analysis of quantitative data in this study used SPSS 23.0 program. The conclusions that can be drawn from this study are the students' mathematical ability with field independent cognitive style were higher than the students with field dependent cognitive style; there was a significant relationship between mathematical ability and cognitive style in elementary school students. Boys' mathematical abilities were not significantly higher than girls. However, the average mathematical ability of boys was higher than girls. Furthermore, there was no relationship between mathematical ability and gender in elementary school students. Judging from the number of students correct answer on the questions of stuffing in algebraic form, the average students who answered correctly on all questions was $69.9 \%$ and the classification was good enough.
\end{abstract}

Keywords-Mathematical Ability, Cognitive Style, Gender

\section{INTRODUCTION}

Mathematics is one of the compulsory subjects in the curriculum of primary and secondary education. This is because mathematics is a knowledge that can improve the ability to think and solve daily problems and the workplaces [1]. The higher the level of education, the higher the high order thinking skills needed. Mathematical ability in elementary school students is a foundation to support thinking skills at higher levels. This is because mathematical concepts are structured in a hierarchical, structured, logical and systematic from the simplest to the complex concept [2].
Mathematical ability is the ability to do mathematics that is measured in the categories of quantitative ability, causal ability, spatial ability, qualitative ability, as well as inductive and deductive abilities [3]. According to the Organization for Economic Cooperation and Development (OECD), fundamental mathematical capabilities among others are communication, mathematicing, representation, reasoning and argument, devising strategies, using symbolic of formal and technical language and operations, and using mathematical tools [21]. Furthermore, mathematical ability is a complex ability that students need to possess in solving mathematical problems.

In fact, there are many things that affect students' mathematical abilities both physically and mentally. In this respect, it is interesting to note that two of them are cognitive styles and gender. Things that affect how students learn can be a way of processing and interpreting information obtained in the classroom. The cognitive style itself is recognized as an important psychological dimension that refers to the difference in the way individuals acquire and process information [4]. The ability to solve math problems in a variety of different ways is influenced by cognitive style [5]. Cognitive style also describes a personality dimension that influences attitudes, values, and social interactions. Furthermore, the improvement of the cognitive processes in students requires attention to the characteristics of each individual student [5].

The cognitive style dimension in this study particularly focuses on field dependent (FD) and field independent (FI). The fundamental difference between these two cognitive styles is seen on how students perceive a problem. Students with FI cognitive style tend to be more analytical in looking at a problem than students with FD cognitive style [6]. Another fact mentioned that students with FD cognitive style find difficulties in processing, but easy to interpret when the information is manipulated according to context. They will be able to separate the stimuli in context, but the perceptions are weak when the context changes [7]. Meanwhile, students with FI cognitive style tend to use internal factors as direction in processing information and perform tasks which are not sequentially [7]. In the other words, students with FD cognitive style prefer to solve problems in a predetermined manner, whereas students with cognitive 
style FI are more analytical and free to express with ideas in solving problem.

Furthermore, gender in mathematics learning is also interesting to discuss. If we hear the word "gender", it is often associated with sex (male and female). In fact, the meaning of gender differs from sex. Based on the Oxford English Dictionary, gender refers to differences in men and women based on cultural and social differences (masculine, feminine, or neutral), whereas sex refers to biological (natural) differences as men and women [8]. In other words, gender is considered as a social construction and gender differences are considered contextually and non-permanently bound, as they are not genetic [9]. Based on some studies, for example, the study conducted at Australian elementary school students on the students aged 8-11 years, the mathematical ability of boys is superior to girls [10]. This is similar to the research of mathematical ability in elementary school students in Germany [11]. The report of PISA 2015 states that gender differences in science tend to be small, but on average in 33 OECD member countries, the topperforming students in science of boys are bigger than girls. However, Finland is the only country where girls are more likely top performers than boys [22].

This difference in mathematical ability based on gender is because girls have less spatial experience outside school than boys. Many girls are less likely to explore their potential to think spatially unless the spatial thinking which is taught in the school curriculum [12]. In addition, girls who are superior in mathematical communication skills (verbal) are more motivated and organized in learning. Further, boys are superior in reasoning and have better mathematical and mechanical skills while women are superior in accuracy, precision, thoroughness, and thoughtfulness. This distinction is not real at the elementary school level, but becomes more apparent at a higher level [12].

Based on the description above, the purpose of this study are:

1) To examine the relationship between mathematical ability and cognitive style at elementary school students.

2) To examine whether the mathematical ability of students with FI cognitive style is higher than students with FD cognitive style.

3) To examine the relationship between mathematical ability and gender at elementary school students.

4) To examine whether the mathematical ability of boys is higher than girls.

\section{METHOD}

The research method is a procedural part as an effort to answer the research problem. This study was conducted as an attempt to examine mathematical skills based on cognitive style and gender in elementary school students. To answer this research question, quantitative survey research was done by providing mathematical ability test and Group Embedded Figure Test (GEFT).

\section{A. Research Subject}

The subjects of this study were 141 elementary school students in Banjarmasin taken from five samples: 35 students in North Banjarmasin, 23 students in South Banjarmasin, 29 students in Central Banjarmasin, 25 students in West Banjarmasin, and 29 students in East Banjarmasin. The five samples have the same character that is the fourth grade students who have studied the material related to this research. The students come from five different schools from each sub-district in Banjarmasin.

\section{B. Data Collection}

Data collection in this study used a test instrument: a multiple choice test and a short-answer test to measure the mathematical ability, and Group Embedded Figure Test (GEFT) to determine the cognitive style of students in each school. The multiple choice test of 25 questions were standard questions taken from the national mathematics exam in 2015. The five short-answer test is a matter of algebra with two of them were open-ended questions. The time given for this test was 90 minutes.

Furthermore, the Group Embedded Figure Test (GEFT) is a standard test used to determine the level of a person's cognitive style [13] [14] [15]. This test consisted of three parts for 15 minutes. Part 1 was part of the exercise, which contained 7 relatively easy forms. Parts 2 and 3 contained 9 forms each. Only sections 2 and 3 were scored, with the highest score of 18 . This cognitive style dimension consisted of dependent fields (scores 0 to 9) and independent fields (scores 10 to 18). Each correct answer was given a value 1. Problem solving is considered "true" if the student succeeds in finding a simple form in a complicated form. The found form must have the same size, comparison, and direction. The reliability coefficient of GEFT has been calculated by previous research with Cronbach alpha, which was 0.84 [16]. This means that GEFT reliability belongs to high reliability.

\section{RESUlTS AND DISCUSSION}

The results of this study were quantitative data obtained through mathematical ability test and Group Embedded Figure Test (GEFT). Data were obtained from 141 elementary school students in Banjarmasin city. Prior to further inferential statistical testing, normality and homogeneity test were performed on independent variables (mathematical ability of students) with SPSS 23.0 program. The normality test of this study was performed by Kolmogorov-Smirnov test, with Asymp value. Sig. 0.05 which means that the data were normally distributed. Then, the homogeneity test data used Levene test with Sig. value 0.161 which means that the data were homogeneous. After the assumption test was met, description of data processing of cognitive style, gender, and mathematical ability of elementary school students were analyzed.

\section{A. Mathematical Ability and Cognitive Style in Elementary School Students}

The mathematical ability instrument analyzed was multiple choice test. The analysis of mathematical ability scores and 
cognitive style (FD and FI) of elementary school students in descriptive statistics can be seen in Table I.

TABlE I. Data of Mathematical Ability and Cognitive Style

\begin{tabular}{|c|c|c|c|c|c|}
\hline Cognitive Style & $\mathbf{N}$ & $\overline{\boldsymbol{X}}$ & SD & $\boldsymbol{x}_{\min }$ & $\boldsymbol{x}_{\max }$ \\
\hline FD & 116 & 15.02 & 4.390 & 5 & 24 \\
\hline FI & 25 & 20.28 & 3.612 & 12 & 25 \\
\hline
\end{tabular}

Based on Table I above, it can be seen that from 141 students, 116 students were with FD cognitive style and students with cognitive style FI were as many as 25 students. This means that most elementary students have a FD cognitive style. Students with FD cognitive style are difficult to process, yet easily interpreted when the information was manipulated according to the context [7]. This is corroborated by Piaget's statement that elementary school students are at the concrete operational stage. At this stage, students are able to understand the existing definition and re-reveal it. However, it has not been able to formulate its own definitions properly, and has not been able to master abstract ideas and verbal symbols [17].

Table I also shows that students with FI cognitive style have higher means of mathematical ability scores than the students with FD cognitive style. This is consistent with the minimum score and maximum score in students with FI cognitive style which were higher than students with FD cognitive styles. The cognitive style differences of FD and FI on students' mathematical abilities are strengthened through inferential statistical analysis. The average difference test was performed with two independent samples T-test obtained Sig value $0.000<$ $\alpha=0.05$. This means that the mean of mathematical ability of students with FI cognitive style is significantly higher than students with FD cognitive style. The facts of this study are corroborated by the assertion that students with FI cognitive style tend to be more analytical in viewing a problem than students with FD cognitive style [6], thus it influences their learning outcomes.

Furthermore, to know the relationship of cognitive style with mathematical ability of elementary school students, correlation and regression test were done. This can be seen in Table II below.

TABLE II. CORRELATION BETWEEN MATHEMATICAL ABILITy AND COGNITIVE STYLE

\begin{tabular}{|l|l|c|}
\hline \multicolumn{3}{|c|}{ Cognitive Style } \\
\hline \multirow{3}{*}{ Mathematical Ability } & Pearson Correlation & 0.429 \\
\cline { 2 - 3 } & Sig. (2-tailed) & 0.000 \\
\cline { 2 - 3 } & $\mathrm{N}$ & 141 \\
\hline
\end{tabular}

Table II shows the value of Pearson Correlation obtained by 0.429 and the value of Sig. was $0.000<0.05$, meaning that there is a significant relationship between mathematical ability and cognitive style of elementary school students.

Subsequently, a simple regression analysis of mathematical ability score (Y) and cognitive style (X) was performed which resulted in a constant of 9.754 and regression $b$ of 5.263. This means that the regression equation between mathematical ability and cognitive style is $\hat{Y}=9.754+5.263 \mathrm{X}$. Regression test based on ANOVA table obtained the value of $F$ for 31.309 with the value of Sig. 0.000. Because of the significance value of $0.000<\alpha=0.05$, it can be concluded that the coefficient of regression equation is significant. Furthermore, the analysis to see the magnitude of the effect of X on Y was done by looking at the coefficient of determination on regression analysis. $\mathrm{R}$ Square value obtained was 0.184 or $18.4 \%$. This value indicates that $18.4 \%$ students' mathematical ability is influenced by cognitive style through linear relationship, while $81.6 \%$ is influenced by other factors. This means that the higher the student's cognitive style, the higher the mathematical ability is. That is, the more students who have FI cognitive style, the higher the achievement of mathematical ability. This cognitive style is indispensable to students in solving mathematical problems because mathematical characteristic is abstract, as well as problems in mathematics require solutions and solutions in detail to obtain correct results [18].

\section{B. Mathematical Ability and Gender in Elementary School Students}

The analyzed mathematical ability instrument was multiple choice test. The analysis of mathematical ability scores and gender of elementary school students in descriptive statistics can be seen in Table III below.

TABLE III. DATA OF MATHEMATICAL ABILITY AND GENDER

\begin{tabular}{|c|c|c|c|c|c|}
\hline Gender & $\mathbf{N}$ & $\bar{X}$ & SD & $\boldsymbol{x}_{\min }$ & $\boldsymbol{x}_{\max }$ \\
\hline Boys & 60 & 16.55 & 4.044 & 9 & 25 \\
\hline Girls & 81 & 15.51 & 5.119 & 5 & 24 \\
\hline
\end{tabular}

Based on Table III above, it appears that 141 elementary school students involved in this study consisted of 60 boys and 81 girls. The mean of mathematical ability score of boys was higher than girls. This is consistent with the minimum score and maximum score by boys higher than girls. This fact is reinforced by previous studies which suggest that the mathematical ability of boys is superior to girls [11][10].

This needs to be reinforced by inferential statistical analysis. The mean difference test was performed with two independent samples T-test obtained Sig value. $0.097>\alpha=0.05$. This means that the mathematical ability of boys is not significantly higher than girls. This is reinforced by previous research which states that the difference in mathematical ability is not real at the elementary school level but becomes more apparent at a higher level [12]. Both boys and girls have their own advantages. Boys are superior in reasoning and have better mathematical and mechanical abilities, while girls are superior in accuracy, precision, rigor, and thoughtfulness [12].

Furthermore, to know the relationship of mathematical ability and gender of elementary school students, the correlation test was done. The result can be seen in Table IV below. 
TABLE IV. CORRELATION BETWEEN MATHEMATICAL ABILITY AND GENDER

\begin{tabular}{|l|l|c|}
\hline \multicolumn{3}{|c}{ Gender } \\
\hline \multirow{3}{*}{ Mathematical Ability } & Pearson Correlation & -0.110 \\
\cline { 2 - 3 } & Sig. (2-tailed) & 0.194 \\
\cline { 2 - 3 } & $\mathrm{N}$ & 141 \\
\hline
\end{tabular}

Table IV shows that the Pearson Correlation value obtained -0.110 and the Sig value was $0.194>0.05$, meaning there is no significant relationship between mathematical ability and gender of elementary school students.

Limitations in this study are not measuring other aspects that can affect students' mathematical ability. In addition, in this study the measured mathematical ability is less detailed and general, such as measuring problem solving ability, representation, reasoning, and others.

\section{Mathematical Ability of Elementary School Students}

In the previous discussion, we have analyzed the students' mathematical ability with multiple choice test. In this section, the instrument of mathematical ability was using a short-answer test. The short-answer test consisted of 5 items, which was a matter of algebra and 2 of them were open-ended item. Each problem was analyzed by looking at the number of students who answered correctly on the matter. The following table shows the percentage of students who answered correctly from all subjects (141 students).

TABle V. Percentage of Correct ANSWER ON EVERy ITEM

\begin{tabular}{|c|c|c|}
\hline Item & Number of Students Replied Correct & $\mathbf{\%}$ \\
\hline 1 & 130 & 92.2 \\
\hline 2 & 69 & 48.9 \\
\hline 3 & 118 & 83.7 \\
\hline 4 & 104 & 73.8 \\
\hline 5 & 70 & 49.6 \\
\hline \multicolumn{2}{|c|}{ Mean } & 69.9 \\
\hline
\end{tabular}

Table $\mathrm{V}$ above shows that the mean of students to answer correctly on all questions was $69.9 \%$. This percentage indicates that the ability of elementary school students to solve algebraic problems is good enough. Furthermore, students who answered number 1 correctly were as much as $92.2 \%$. In question number 2 , students who answered correctly were as much as $48.9 \%$. Students answered correctly about the number 3 as much as $83.7 \%$. Students answered number 4 correctly as much as $73.8 \%$ and the number 5 as much as $49.6 \%$. The facts show that item 2 and 5 are difficult. Students' ability to solve algebra problems needs to be improved. In fact, algebra has been widely recognized as one of the most difficult topics which leads to learning difficulties worldwide [19]. This suggests that the algebra problem belongs to a high-order thinking ability.

\section{CONCLUSIONS}

Based on the theoretical review and supported by hypothesis test that refers to the purpose of this study, it can be concluded that the mathematical ability of students with FI cognitive style is higher than students with FD cognitive style; there is a significant relationship between mathematical ability and cognitive style in elementary school students. Boys' mathematical ability is not significantly higher than girls although the mean of boys mathematical ability of is higher than girls. Furthermore, there is no relationship between mathematical ability and gender in elementary school students. Judging from the number of students who correctly answered the short-answer test in algebraic form, the means of students correct answer on all items is $69.9 \%$. The percentage indicates that the ability of elementary school students in Banjarmasin in solving algebra problem is good enough.

\section{ACKNOWLEDGMENT}

Thanks to the schools and students who bacame the subjects of our research; Muhammad Nabili, S.Pd. who assisted the data collection; and FKIP Universitas Lambung Mangkurat.

\section{REFERENCES}

[1] D. P. Sari and Mahendra, "Developing instrument to measure mathematical reasoning ability," in International Conference of Mathematics and Science Education, 2017.

[2] H. Soeprianto, "Penerapan pembelajaran nilai-nilai yang terintegrasi dalam mata pelajaran matematika," Jurnal EducatiO, vol. 4, no. 2, pp. 29-37, 2009.

[3] B. Sriraman, P. Haavold and K. Lee, "Creativity in mathematics education," in Encyclopedia of Mathematics Education, London, Springer Reference, 2014, pp. 109-115.

[4] L. J. Ausburn and F. B. Ausburn, "Cognitive styles: some information and implications for instructional design," Educational Technology Research and Development, vol. 26, no. 4, pp. 337-354, 1978.

[5] S. Widadah, D. S. N. Afifah and Suroto, "Profil metakognisi siswa dalam menyelesaikan soal sistem persamaan linear dua variabel berdasarkan gaya kognitif," Jurnal Pendidikan Matematika STKIP PGRI Sidoarjo, vol. 1, no. 1, pp. 13-24, 2013.

[6] D. A. Ngilawajan, "Proses berpikir siswa sma dalam memecahkan masalah matematika materi turunan ditinjau dari gaya kognitif field independent dan field dependent," Pedagogia, vol. 2, no. 1, pp. 71-83, 2013.

[7] B. Usodo, "Profil intuisi mahasiswa dalam memecahkan masalah matematika ditinjau dari gaya kognitif field dipendent dan field independent," in Prosiding Seminar Nasional Matematika dan Pendidikan Matematika UNS, 2011.

[8] D. Haig, "The inexorable rise of gender and the decline of sex: social change in academic titles, 1945-2001," Archives of Sexual Behavior, vol. 33, no. 2, pp. 87-96, 2004.

[9] H. Forgasz, "Gender in Mathematics Education," in Encyclopedia of Mathematics, London, Springer Reference, 2014, pp. 243-247.

[10] J. L. Arnup, C. Murrihy, J. Roodenburg and L. A. McLean, "Cognitive style and gender differences in children's mathematics achievement," Educational Studies, vol. 39, no. 3, pp. 355-368, 2013.

[11] H. Winkelmann, M. van den Heuvel-Panhuizen and A. Robitzsch, "Gender differences in the mathematics achievements of german primary school students: results from a german large-scale study," ZDM Mathematics Education, vol. 40, no. 4, p. 601-616, 2008.

[12] Z. A. MZ, "Perspektif gender dalam pembelajaran matematika," Marwah: Jurnal Perempuan, Agama dan Gender, vol. 12, no. 1, pp. 1531, 2013.

[13] S. Clark, E. Seat and F. Weber, "The performance of engineering students on the group embedded figures test," in ASEElIEEE Frontiers in Education Conference, Kansas, 2000.

[14] T. P. O'Brien, S. M. Butler and L. E. Bernold, "Group embedded figures test and academic achievement in engineering education," International Journal of Engineering Education, vol. 17, no. 1, pp. 89-92, 2001. 
[15] Y.-C. Guo and S.-J. Lou, "A study of learning effects in different cognitive styles in PBL animation," in Second International Conference on Robot, Vision and Signal Processing, 2013.

[16] E. Khodadady and A. Tafaghodi, "Cognitive styles and fluid intelligence: are they related?," Journal of Studies in Social Sciences, vol. 3, no. 2, pp. 138-150, 2013.

[17] Tim MKPBM, Common Text Book: Strategi Pembelajaran Matematika Kontemporer, Bandung: JICA Universitas pendidikan Indonesia (UPI), 2001.

[18] H. Ulya, "Hubungan gaya kognitif dengan kemampuan pemecahan masalah matematika siswa," Jurnal Konseling GUSJIGANG, vol. 1, no. 2, 2015.

[19] A. Jupri, P. Drijvers and M. van den Heuvel-Panhuizen, "Difficulties in initial algebra learning in Indonesia," Mathematics Education Research Journal, vol. 26, no. 4, pp. 683-710, 2014.
[20] "Dictionary," Oxford University Press, 21 March 2017. [Online]. Available: https://en.oxforddictionaries.com/definition/gender.

[21] OECD, PISA 2015 Assessment and Analytical Framework: Science, Reading, Mathematic and Financial Literacy, Paris: OECD Publishing, 2016a.

[22] OECD, PISA 2015 Results (Volume I): Excellence and Equity in Education, Paris: OECD Publishing, 2016b. 